\title{
Effect of zinc supplementation on body mass index and serum levels of zinc and leptin in pediatric hemodialysis patients
}

This article was published in the following Dove Press journal: International Journal of Nephrology and Renovascular Disease 10 December 2015

Number of times this article has been viewed

\author{
Ahmed Nabih El-Shazly' \\ Soha Abd El-Hady Ibrahim' \\ Ghada Mohamed \\ El-Mashad ${ }^{2}$ \\ Jehan H Sabry 3 \\ Nashwa Said Sherbini' \\ 'Department of Pediatrics, Faculty of \\ Medicine, Benha University, Banha, \\ ${ }^{2}$ Department of Pediatrics, Faculty of \\ Medicine, Menoufia University, Shibin \\ Al Kawm, ${ }^{3}$ Department of Clinical \\ and Chemical Pathology, Faculty of \\ Medicine, Benha University, Banha, \\ Egypt
}

Introduction: Zinc is an essential trace element for human nutrition, and its deficiency is associated with anorexia, poor food efficiency, growth retardation, and impaired neurological and immune systems. The zinc-deficiency rate is particularly high in many disease states, such as with end-stage renal disease patients undertaking hemodialysis. The aim of this study was to determine the effect of zinc supplementation on body mass index (BMI) and serum levels of zinc and leptin in pediatric hemodialysis patients.

Patients and methods: This was a prospective clinical trial study in which 60 hemodialysis patients were randomly divided into two groups: group I received 50-100 mg zinc sulfate (equivalent to 11-22 mg elemental zinc) according to age, sex, and nutritional status of the child; and group II received placebo (cornstarch) twice daily for 90 days. Anthropometric measurements were taken, and serum zinc and leptin levels were determined by colorimetric test with 5-Br-3'-phosphoadenosine-5'-phosphosulfate and enzyme-linked immunosorbent assay, respectively, at days 0 and 90 of the study.

Results: Zinc supplementation resulted in a significant increase in mean serum zinc level and BMI. Serum leptin decreased significantly after supplementation in children under hemodialysis. A significant negative correlation was observed between serum zinc and leptin levels as a result of zinc supplementation.

Conclusion: There was an increase in serum zinc level and BMI and decreased serum leptin after zinc supplementation in children under hemodialysis.

Keywords: serum zinc, serum leptin, hemodialysis, body weight

\section{Introduction}

Zinc is an essential trace metal for human nutrition; it is vital for several body functions, such as cell reproduction, growth, immunity, vision, and cognition. It plays an important role in metabolism, particularly as a cofactor of many enzymes, required for natural metabolic processes. ${ }^{1}$

There is an association between zinc deficiency and growth retardation, immune system disturbances, poor nutritional status, and high rates of infections. ${ }^{2}$ Research has shown decreased zinc plasma levels in patients with chronic kidney insufficiency conservatively treated or on hemodialysis (HD). ${ }^{3}$ Serum zinc deficiency has been reported in chronic kidney disease (CKD) patients due to hypoproteinemia, tubular reabsorption impairment, proteinuria, and calcitriol deficiency, which has a role in zinc absorption from the intestine. ${ }^{4}$

Leptin is an adipocytokine that limits food intake and increases energy expenditure by acting on the hypothalamus, ${ }^{5}$ and it may offer a tool for making clear the
Correspondence: Nashwa Said Sherbini Pediatric Department, Benha Teaching Hospital, I Bahary El-Taameen El-Sehy Street Benha, Qualyuobeya I31 I I, Egypt Tel +20 I0 04930982

Email nashwa_sherbeny@yahoo.com 
physiology of zinc deficiency-induced anorexia according to the relationship between zinc and leptin levels. ${ }^{6}$ Patients with chronic renal failure have a high level of serum leptin due to decreased renal clearance; ${ }^{7}$ also, leptin is thought to be related to malnutrition, changes in body composition, and chronic inflammation in HD patients. ${ }^{8}$

The relationship between zinc and leptin has been previously investigated in HD patients, ${ }^{6}$ but there have been no studies investigating the effect of zinc supplementation in children under HD. Therefore, the aim of this work was to determine the effect of zinc supplementation on serum zinc and leptin levels and body mass index (BMI) in pediatric HD patients.

\section{Patients and methods}

This was a prospective clinical trial conducted on 60 children between 5 and 18 years old on regular HD at the pediatric dialysis units, Benha University and Menoufia University hospitals. This study was approved by the ethics committee of Benha University of Medicine.

The selected patients were on regular HD three times weekly for a minimum of 6 months. Patients with diabetes, malignancy, or gastrointestinal disorders were excluded. Patients were randomly divided into two groups: group I (supplemented group, $\mathrm{n}=40$ ) received zinc sulfate supplementation, and group II (control, $\mathrm{n}=20$ ) received placebo (cornstarch capsules) twice daily for 90 days.

The mean age of group I (21 females and 19 males) was $13.8 \pm 3.1$ years, and the mean age of the control group (ten males and ten females) was $12.5 \pm 3.1$ years. Written informed consent was obtained from all patients or guardians after explaining the purpose of the study and the importance of zinc supplementation and complications with its deficiency.

Patients (supplemented group) were on a daily supplementation of zinc sulfate (50-100 mg zinc sulfate [equivalent to 11-22 mg elemental zinc]), according to age, sex, and nutritional status of each child, to be taken during or after food without other medication for 90 days, with strict regular follow-up of zinc intake.

A full medical history was taken, focusing on nutritional history (regarding quality and quantity of food rich in zinc), etiology and duration of the original renal disease, and history of medication and supplementation. Anthropometric measures were body weight $(\mathrm{kg})$ of the patients, which was measured with little clothing, height $(\mathrm{cm})$, which was measured with bar foot, and BMI $\left(\mathrm{kg} / \mathrm{m}^{2}\right)$, which was calculated as weight divided by height squared.
Predialysis, $4 \mathrm{~cm}$ of venous blood samples were collected into metal free tubes and centrifuged after fasting all night. Serum samples were stored at $-20^{\circ} \mathrm{C}$ until analysis (divided into two samples: one for leptin, and the other for zinc) before zinc supplementation. A second similar sample was taken after zinc supplementation.

\section{Zinc determination}

Determination of zinc levels was done using Greiner kits. This zinc-assay kit it is a direct colorimetric assay based on the 5-Br-3'-phosphoadenosine-5'-phosphosulfate (5-Br-PAPS) method without deproteinization of the sample. The zinc determination is based on the reaction of zinc with 5-Br-PAPS at alkaline $\mathrm{pH}$ in a buffered media, which forms a stable colored complex. The color intensity is proportional to the zinc concentration in the sample. Absorbance of the $\mathrm{Zn}^{2+}$ complex is measured at $560 \mathrm{~nm}^{9}$

\section{Leptin determination}

This was done using a DRG leptin enzyme-linked immunosorbent assay (ELISA) kit. The leptin kit is a solid-phase sandwich. A monoclonal antibody specific for human leptin has been coated onto the wells of the microtiter strips provided. Standards, control specimens, and unknowns are pipetted into these wells, followed by the addition of a secondary biotinylated monoclonal antibody.

During the first incubation, the leptin antigen binds to the immobilized (capture) antibody on one site and to the solution-phase biotinylated antibody on a second site. After removal of excess second antibody, streptavidin-peroxidase (enzyme) is added. This binds to the biotinylated antibody to complete the four-member sandwich. After a second incubation and washing to remove all the unbound enzyme, a substrate solution is added, which is acted upon by the bound enzyme to produce color. The intensity of this colored product is directly proportional to the concentration of leptin present in the original specimen. ${ }^{10}$

\section{Statistical analysis}

The collected data were tabulated and analyzed using SPSS version 16 software (SPSS Inc., Chicago, IL, USA). Categorical data are presented as number and percentages, while quantitative data are expressed as means and standard deviation, or median and range. Student's $t$-test, paired $t$-test, Spearman's correlation coefficient $(\rho)$, Mann-Whitney $U$ test, Wilcoxon test, and Kruskal-Wallis test were used as tests of significance. Stepwise multiple linear regression analysis was used to detect the significant predictors of zinc 
Table I Mean \pm SD of serum zinc, serum leptin, body weight, and BMI in both the studied groups

\begin{tabular}{|c|c|c|c|c|c|c|}
\hline & \multicolumn{3}{|l|}{ Group I } & \multicolumn{3}{|l|}{ Group II } \\
\hline & \multicolumn{3}{|c|}{ Supplemented group $(n=40)$} & \multicolumn{3}{|c|}{ Control group $(n=20)$} \\
\hline & Before & After & $P$-value & Before & After & $P$-value \\
\hline $\mathrm{Zn}(\mu \mathrm{g} / \mathrm{dL})$ & $53.2 \pm 8.15$ & $90.75 \pm 12.2$ & $<0.001$ & $55.45 \pm 9.1$ & $55.35 \pm 9.15$ & 0.17 \\
\hline Leptin (ng/mL) & $8.03 \pm 4.6$ & $6.34 \pm 4.3$ & 0.041 & $8.9 \pm 6$ & $8.6 \pm 6$ & 0.51 \\
\hline Body weight (kg) & $34.0 \pm 16.07$ & $35.1 \pm 16.6$ & $<0.001$ & $38 \pm 19.52$ & $37.97 \pm 19.52$ & 0.65 \\
\hline BMI $\left(\mathrm{kg} / \mathrm{m}^{2}\right)$ & $18.7 \pm 5.8$ & $19.02 \pm 6.0$ & $<0.001$ & $19.91 \pm 6.08$ & $19.95 \pm 6.13$ & 0.96 \\
\hline
\end{tabular}

Abbreviations: SD, standard deviation; BMI, body mass index.

level. The accepted level of significance in this work was set at $0.05(P<0.05) .{ }^{11}$

\section{Results}

The most common causes of renal failure in our patients were congenital anomaly (22.5\%), chronic glomerulonephritis $(17.5 \%)$, and chronic obstructive uropathy (17.5\%), while the least common causes were systemic lupus erythematosus (5\%) followed by Alport syndrome (3\%).

No significant difference between two groups (supplemented and control) at the beginning of the study was observed (Table 1). Serum zinc mean levels were 53.2 \pm 8.15 in group I and $55.45 \pm 9.1 \mu \mathrm{g} / \mathrm{dL}$ in group II, which were in the lower-than-normal range of serum zinc in normal children of the same age and sex $(63.8-110 \mu \mathrm{g} / \mathrm{dL}){ }^{9}$ After 90 days of study, the mean serum zinc level had highly significantly increased from $53.2 \pm 8.15 \mu \mathrm{g} / \mathrm{dL}$ to $90.75 \pm 12.2 \mu \mathrm{g} / \mathrm{dL}(P<0.001)$ while it remained unchanged in the control group (Figure 1).

The mean serum leptin was $8.03 \pm 4.6 \mathrm{ng} / \mathrm{dL}$ in group I and $8.9 \pm 6 \mathrm{ng} / \mathrm{mL}$ in group II before supplementation, but after 90 days of study, the mean serum leptin level had significantly decreased $(P<0.04)$ in group I, while it remained

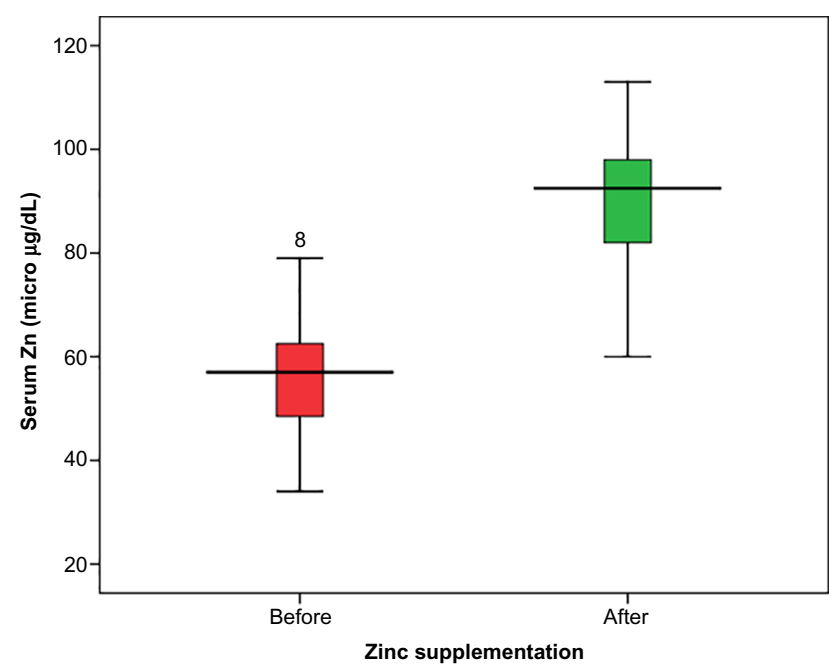

Figure I Box plot comparing serum zinc levels before and after zinc supplementation in the supplemented group. unchanged in group II. Also it was observed that body weight and BMI were highly significant increased $(P<0.001)$ after a period of supplementation in group I, while there was no change in group II.

There was a statistically significant negative correlation $(P<0.05)$ between both serum zinc and serum leptin levels and duration of dialysis. However, there was a statistically significant positive correlation of serum zinc with both body weight and BMI, but no statistically significant correlation of serum zinc with age or height among the study group after zinc supplementation (Table 2).

In this study, mean serum leptin was higher in females than males, while mean serum zinc and BMI were higher in males than females, but there was no statistical significance according to sex (Table 3). Factors found to be significantly correlated with zinc level (weight, BMI, leptin, and duration of dialysis) were entered into the stepwise multiple linear regression model. It was found that only leptin level and BMI were significant predictors of Zinc level (Table 4).

\section{Discussion}

Zinc is a trace element that is proving vital for a number of human biological processes. Almost all cells have a requirement for zinc at some level. ${ }^{12}$ During dialysis, some trace element may enter the dialysate from blood, while others can accumulate in the body, leading to trace-element disturbance. ${ }^{13}$

Table 2 Correlation between serum zinc level and the studied variables after intervention in the study group

\begin{tabular}{lll}
\hline Variable & \multicolumn{2}{l}{ Serum zinc $(\mu \mathrm{g} / \mathrm{dL})$} \\
\cline { 2 - 3 } & $\rho$ & $\boldsymbol{P}$ \\
\hline Age (years) & -0.225 & 0.16 \\
Height $(\mathrm{cm})$ & 0.156 & 0.34 \\
Weight $(\mathrm{kg})$ & 0.511 & $0.01 \mathrm{I}^{*}$ \\
BMI $\left(\mathrm{kg} / \mathrm{m}^{2}\right)$ & 0.490 & $0.021^{*}$ \\
Serum leptin $(\mathrm{ng} / \mathrm{mL})$ & -0.454 & $0.03^{*}$ \\
Duration of dialysis & -0.450 & $0.04^{*}$ \\
\hline
\end{tabular}

Note: $* P<0.05$.

Abbreviation: BMI, body mass index. 
Table 3 Mean \pm SD of serum zinc, serum leptin, and body mass index in males and females in group I (supplemented group)

\begin{tabular}{llllll}
\hline & \multicolumn{2}{l}{ Male $(\mathbf{n = 1 9 )}$} & & \multicolumn{2}{l}{ Female $(\mathbf{n}=21)$} \\
\cline { 2 - 3 } \cline { 5 - 6 } \cline { 5 - 6 } & Before & After & & Before & After \\
\hline Zn $(\mu \mathrm{g} / \mathrm{dL})$ & $54 \pm 8.25$ & $92.9 \pm 10.5$ & & $53.98 \pm 8.26$ & $88.76 \pm 13.54$ \\
Leptin $(\mathrm{ng} / \mathrm{mL})$ & $7.04 \pm 4.6$ & $5.86 \pm 4.3$ & & $8.92 \pm 6.9$ & $6.78 \pm 6$ \\
BMl $\left(\mathrm{kg} / \mathrm{m}^{2}\right)$ & $20.29 \pm 7.04$ & $21.52 \pm 7.29$ & & $17.32 \pm 4.08$ & $17.67 \pm 4.19$ \\
\hline
\end{tabular}

Abbreviations: SD, standard deviation; BMI, body mass index.

In this study, the most common causes of renal failure in our patients were congenital anomalies, followed by chronic obstructive uropathy and chronic glomerulonephritis. This is consistent with Harambat et al, who showed that congenital anomalies of the kidney and urinary tract are the most common cause of renal failure (48\%), followed by glomerulonephritis (14\%) and hereditary nephropathies $(10 \%) .{ }^{14}$

In this study, before zinc supplementation, mean serum zinc level in patients was $54 \pm 8.1 \mu \mathrm{g} / \mathrm{dL}$, which is less than the lower limit of normal range for children $(63.8-110 \mu \mathrm{g} / \mathrm{dL})$. A study has reported that a lot of CKD patients (either under conservative treatment or dialysis) have zinc deficiency. ${ }^{15}$ Anees et al clarified different causes of decreased serum zinc level in HD patients as decreased zinc intake and dietary restriction. ${ }^{16}$ Also, the etiologies of zinc deficiency reported by Dashti-Khavidaki et al were tubular reabsorption impairment, losses by dialysate, proteinuria, and hypoproteinemia. ${ }^{4}$

The results of the present study showed that serum zinc concentrations after zinc supplementation increased from $53.2 \pm 8.15$ to $90.75 \pm 12.2 \mu \mathrm{g} / \mathrm{dL}$ (within normal ranges). This is consistent with previous findings that showed improvement of serum zinc concentrations in the HD population after zinc supplementation. ${ }^{3,17}$

In this study, before zinc supplementation, serum leptin level in patients was $8.03 \pm 4.6 \mathrm{ng} / \mathrm{mL}$, which was higher in females compared to males. This higher concentration of leptin in females agrees with previous research, ${ }^{18}$ and similar to

Table 4 Stepwise multiple linear regression analysis for factors affecting zinc level

\begin{tabular}{llll}
\hline Variables & $R^{2}$ (adjusted $\left.R^{2}\right)$ & $0.376(0.342)$ \\
& $F_{2,37}$ and $P_{\text {model }}$ & II.I and $<0.00 \mathrm{I}$ \\
& $\mathrm{b}_{0}$ & 65.07 & \\
& $\boldsymbol{\beta}$ & $\boldsymbol{P}$ & $\mathbf{9 5 \%} \mathrm{Cl}$ of $\beta$ \\
\hline Leptin level & $-0.26 \mathrm{I}$ & $<0.00 \mathrm{I}$ & -0.399 to -0.123 \\
& 0.498 & & \\
BMI & -0.469 & 0.014 & -0.840 to -0.099 \\
& -0.334 & & \\
\hline
\end{tabular}

Notes: $Y=b_{0}+b_{1} X_{1}+b_{2} X_{2} ;$ zinc level $=65.07-(0.261 \times$ leptin level $)-(0.469 \times B M I)$. Abbreviations: $\mathrm{Cl}$, confidence interval; $\mathrm{BMI}$, body mass index.
Aranha et al, who observed that low plasma zinc levels were negatively associated with high leptin levels in HD patients. ${ }^{6}$ Impairment of glomerular filtration in patients with renal insufficiency may lead to leptin-level elevation, which may cause loss of appetite and protein-energy malnutrition in patients with renal insufficiency. ${ }^{7}$

Although not all patients with CKD have elevated serum leptin levels as reported in some studies, a significant elevation is noted when such levels are adequately corrected for age and body-fat mass. ${ }^{19,20}$ Investigators have hypothesized that lung, liver, or muscle tissues could play a role in leptin metabolism, as these tissues also express leptin-receptor messenger RNA. However, in the presence of normal renal function, no plasma removal of leptin via lung, liver, or muscle tissue has been observed. ${ }^{21}$

The result of our study showed that the mean serum leptin level in patients was $6.34 \pm 4.3 \mathrm{ng} / \mathrm{mL}$ after zinc supplementation, with significant negative correlation between serum zinc and leptin. Argani et al showed that mean serum leptin decreased significantly after zinc supplementation in adults, but the mechanisms by which serum leptin level is affected as a result of zinc supplementation in HD patients needed to be clarified. ${ }^{13}$

Sánchez et al reported that glomerular filtration and consequently serum leptin level were affected positively after zinc supplementation. ${ }^{22}$ Another hypothesis put forward by Mariani et al reported that IL- 6 and subsequently serum leptin levels may be decreased after zinc supplementation. ${ }^{23}$ As Trujillo et al demonstrated, IL-6 has multiple effects in human adipose tissue and most importantly, IL-6 could increase leptin production. ${ }^{24}$

In our study, there was a statistically significant increase in both weight and BMI after zinc supplementation. These results agree with previous findings that oral zinc supplementation improved appetite and stimulated food intake. ${ }^{25,26} \mathrm{Also}$, the results of our study showed that there was a significant negative correlation between serum zinc and duration of dialysis, which agrees with the results of Anees et al and Esfahani et al, which showed that duration of dialysis had a negative correlation with serum zinc level. ${ }^{16,27}$

\section{Conclusion}

Serum zinc level and BMI significantly improved after zinc supplementation, while serum leptin level decreased in children under HD, so we recommend zinc supplementation to all children under HD to improve their appetite and build. 


\section{Disclosure}

The authors report no conflicts of interest in this work.

\section{References}

1. Fukada T, Yamasaki S, Nishida K, Murakami M, Hirano T. Zinc homeostasis and signaling in health and diseases: zinc signaling. J Biol Inorg Chem. 2011;16(7):1123-1134.

2. Yang CY, Wu ML, Chou YY, et al. Essential trace element status and clinical outcomes in long-term dialysis patients: a two-year prospective observational cohort study. Clin Nutr. 2012;31(5):630-636.

3. Guo CH, Wang CL, Chen PC, Yang TC. Linkage of some trace elements, peripheral blood lymphocytes, inflammation and oxidative stress in patients undergoing either hemodialysis or peritoneal dialysis. Perit Dial Int. 2011;31(5):583-591.

4. Dashti-Khavidaki S, Khalili H, Vahedi SM, Lessan-Pezeshki M. Serum zinc concentrations in patients on maintenance hemodialysis and its relationship with anemia, parathyroid hormone concentrations and pruritus severity. Saudi J Kidney Dis Transpl. 2010;21(4): 641-645.

5. Anshu K, Tanu A, Parshant C, Neena S, Sunita T, Payal M. Plasma leptin levels and body mass index in north Indian subjects: correlation with insulin resistance. J Adv Res Biol Sci. 2013;5(1):59-62.

6. Aranha LN, Lobo JC, Stockler-Pinto MB, Leal Vde O, Torres JP, Mafra D. Relationship between zinc levels and plasma leptin in hemodialysis patients. J Trace Elem Med Biol. 2012;26(4): 238-242.

7. Daschner M, Tönshoff B, Blum WF, et al. Inappropriate elevation of serum leptin levels in children with chronic renal failure. European Study Group for Nutritional Treatment of Chronic Renal Failure in Childhood. J Am Soc Nephrol. 1998;9(6):1074-1079.

8. Jerin L, Ladavac R, Kuzmanović G, Dodić D, Griparić D. [Subjective general assessment of nutritional status in patients with chronic renal failure and regular hemodialysis]. Acta Med Croatica. 2003; 57(1):23-28. Croatian.

9. Johnsen O, Eliasson R. Evaluation of a commercially available kit for the colorimetric determination of zinc in human seminal plasma. Int $J$ Androl. 1987;10(2):435-440.

10. Considine RV, Sinha MK, Heiman ML, et al. Serum immunoreactiveleptin concentrations in normal weight and obese humans. $N$ Engl J Med. 1996;334(5):292-295.

11. Khothari CR. Research Methodology: Methods and Techniques. New Delhi: New Age International; 2004

12. Huang L. Zinc and its transporters, pancreatic $\beta$-cells, and insulin metabolism. In: Litwack G, editor. Vitamins and Hormones: The Pancreatic Beta Cell. London: Elsevier; 2014:365-390.
13. Argani H, Mahdavi R, Ghorbani-Haghjo A, Razzaghi R, Nikniaz L, Gaemmaghami SJ. Effect of zinc supplementation on serum zinc and leptin levels, BMI, and body composition in hemodialysis patients. J Trace Elem Med Biol. 2014;28(1):35-38.

14. Harambat J, van Stralen KJ, Kim JJ, Tizard EJ. Epidemiology of chronic kidney disease in children. Pediatr Nephrol. 2012;27(3):363-373.

15. Kiziltas H, Ekin S, Erkoc R. Trace element status of chronic renal patients undergoing hemodialysis. Biol Trace Elem Res. 2008; 124(2):103-109.

16. Anees M, Mumtaz A, Frooqi S, Ibrahim M, Hameed F. Serum trace elements (aluminum, copper, zinc) in hemodialysis patients. Biomedica. 2011;27:106-110

17. Rashidi AA, Salehi M, Piroozmand A, Sagheb MM. Effect of zinc supplementation on zinc and C-reactive protein concentrations in hemodialysis patients. J Ren Nutr. 2009;19(6):475-478.

18. Thomas T, Burguer B, Melton J, et al. Relationship of serum leptin levels with body composition and sex steroid and insulin levels in men and women. Metabolism. 2000;49(10):1278-1284.

19. Briley LP, Szczech LA. Leptin and renal disease. Semin Dial. 2006;19(1):54-59.

20. Sharma K, Considine RV, Michael B, et al. Plasma leptin is partly cleared by the kidney and is elevated in hemodialysis patients. Kidney Int. 1997;51(6):1980-1985.

21. Jensen MD, Møller N, Nair KS, Eisenberg P, Landt M, Klein S. Regional leptin kinetics in humans. Am J Clin Nutr. 1999;69(1):18-21.

22. Sánchez C, Aranda P, Pérez de la Cruz A, Llopis J. Magnesium and zinc status in patients with chronic renal failure: influence of a nutritional intervention. Magnes Res. 2009;22(2):72-80.

23. Mariani E, Neri S, Cattini L, et al. Effect of zinc supplementation on plasma IL-6 and MCP-1 production and NK cell function in healthy elderly: interactive influence of +647 MT1a and -174 IL-6 polymorphic alleles. Exp Gerontol. 2008;43(5):462-471.

24. Trujillo ME, Sullivan S, Harten I, Schneider SH, Greenberg AS, Fried SK. Interleukin-6 regulates human adipose tissue lipid metabolism and leptin production in vitro. J Clin Endocrinol Metab. 2004;89(11):5577-5582.

25. Suzuki H, Asakawa A, Li JB, et al. Zinc as an appetite stimulator - the possible role of zinc in the progression of diseases such as cachexia and sarcopenia. Recent Pat Food Nutr Agric. 2011;3(3):226-231.

26. Sahin H, Uyanik F, Inanç N, Erdem O. Serum zinc, plasma ghrelin, leptin levels, selected biochemical parameters and nutritional status in malnourished hemodialysis patients. Biol Trace Elem Res. 2009; 127(3):191-199.

27. Esfahani ST, Hamidian MR, Madani A, Ataei N, Mohseni P, Roudbari M. Serum trace elements in children on maintenance hemodialysis. Acta Med Iran. 2009;45(5):351-354.

\section{Publish your work in this journal}

The International Journal of Nephrology and Renovascular Disease is an international, peer-reviewed open-access journal focusing on the pathophysiology of the kidney and vascular supply. Epidemiology, screening, diagnosis, and treatment interventions are covered as well as basic science, biochemical and immunological studies. The journal welcomes

\section{Dovepress}

original research, clinical studies, reviews \& evaluations, expert opinion and commentary, case reports and extended reports. The manuscript management system is completely online and includes a very quick and fair peerreview system, which is all easy to use. Visit http://www.dovepress.com/ testimonials.php to read real quotes from published authors. 